\title{
"It is not what I planned for my life". Occupations of live-in domestic workers
}

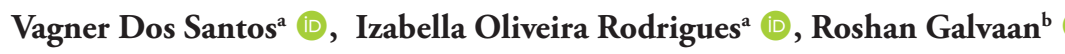 \\ ${ }^{a}$ Universidade de Brasilia - UnB, Brasília, DF, Brasil. \\ ${ }^{b}$ University of Cape Town - UCT, Cape Town, South Africa.
}

\begin{abstract}
Introduction: In Brazil, nearly 20\% of women in the country are domestic workers. Domestic work has a restrictive nature that can lead to occupational deprivation and occupational marginalization. This may be the case of live-in domestic workers in Brazil. Objective: Our research question was: What are Brazilian domestic workers' experiences in participating in their occupations in everyday life? Method: A qualitative phenomenological was carried out and thought purposive sampling 5 participants were selected in the Plano Piloto region, Brasilia, DF, Brazil. Data was collected through face-face interviews and analyzed using Systematic Text Condensation. Results: The data analysis yielded one theme and two categories. The theme, Grappling with being a domestic worker, described the domestic workers ongoing confrontations and tensions experienced in their daily lives. This experience of wresting with the influence of being a domestic worker was constituted through two categories, namely a sense of 'Belonging to the labor role' and 'Exceptionalism: a employers' negotiation tactic'. Conclusion: Our work contributes to a critical perspective of occupation. We focus on how historical, social and political factors contribute to creating oppressive environments that influences domestic workers as people who are part of a marginalized group. This occurs in the way that their occupations are constructed in their doing in every-day life.
\end{abstract}

Keywords: Employment, Occupational Justice, Brazil.

\section{"Náo foi isso que planejei para minha vida". Ocupaçóes de empregadas domésticas que moram no local de trabalho}

Resumo: Introdução: No Brasil, aproximadamente 20\% das mulheres são trabalhadores domésticas. O trabalho doméstico tem uma natureza restritiva, que pode resultar em privação ocupacional e marginalização ocupacional. Esse é possivelmente o caso das trabalhadoras domésticas brasileiras que moram no local de trabalho. Objetivo: Identificar quais são as experiências cotidianas de participação em ocupações destas mulheres. Método: Um estudo qualitativo, de abordagem fenomenológica foi desenvolvido, 5 participantes foram selecionadas no Plano Piloto, em Brasília, DF, Brasil. A coleta de dados foi realizada por entrevistas e analisadas usando Systematic Text Condensation. Resultados: A análise dos dados levou a um tema e duas categorias. O tema 'agarrada em ser empregada doméstica' descreve as constantes confrontações e tensões vividas em suas vidas cotidianas. Essas experiências de lutas em ser empregada doméstica constituem as duas categorias: (i) 'pertencendo ao papel de trabalhadora' e (ii) 'exceções, uma tática de negociação de empregadores'. Conclusão: Nosso trabalho contribui para uma perspectiva crítica da ocupação. Nosso foco em como fatores históricos, sociais e políticos contribuem para criação de ambientes opressivos que resultam em um processo de marginalização da condição de empregada doméstica.

Palavras-chave: Emprego, Justiça Ocupacional, Brasil

Corresponding author: Vagner dos Santos, Faculdade Ceilândia, Universidade de Brasília - UnB, Conjunto A, Lote 1, Centro Metropolitano, CEP 72220-900, Brasília, DF, Brasil, e-mail: vagner@unb.br

Received on Jan. 11, 2019; $1^{\text {st }}$ Revision on Apr. 23, 2019; Accepted on May 20, 2019.

This is an Open Access article distributed under the terms of the Creative Commons Attribution License, which permits unrestricted use, distribution, and reproduction in any medium, provided the original work is properly cited. 


\section{Introduction}

The challenge to provide deeper interpretations of human occupation and its social, economic, cultural, political, dimensions is necessary in occupational science and occupational therapy (FRANK; ZEMKE, 2008; GUAJARDO, 2014). Widespread inequalities along social, racial and geographical lines have historically been consolidated in Brazil (ALMEIDA-FILHO et al., 2004; CHOR, 2013; MCCALLUM, 2005). The influence of social and economic factors on occupations is relevant to live-in domestic workers' experiences when participating in occupations since domestic work is known to be imposing and restrictive in nature (BERNARDINO, 2014; INTERNATIONAL..., 2016). The International Labor Organization reports that about 52,6 million people around the world are employed as domestic workers. The feminization of this work continues due to the acceptance of the naturalization of caretaking as innate to women (ARAUJO; GONZÁLEZ-FERNÁNDEZ, 2014) and is reflected in the high percentage (83\%) of women who were reported to be working as domestic workers internationally (INTERNATIONAL..., 2013). In Brazil, nearly $20 \%$ of women in the country are domestic workers (DIEESE, 2010) which makes it one of the most important labor categories for women. One of the factors contributing to this may be that it is one of the few income options for women with low formal education (INTERNATIONAL..., 2016).

Historically in Brazil, many slaves performed domestic labor during the period of Portuguese colonization (INTERNATIONAL..., 2016) being gender, social class and race inequalities prevalent in the profile of domestic workers (BERNARDINO, 2014; KOFES, 2001; GUTIERREZ-RODRIGUEZ, 2014). The inequality is still reflected in the current demographic profile of domestic workers in Brazil with $79.3 \%$ self-declared as being black, and a high proportion of $42 \%$ of domestic workers in the 25-39 age range (DIEESE, 2010). In Brazil, domestic workers did not have their labor rights fully and formally recognized until 2015 (BRASIL, 2015). Consequently, domestic workers (live-in, part- and full-time workers) have been subject to different forms of exploitation and might, even presently, have little knowledge of their legal rights or ability to claim for them (BERNARDINO, 2014). Additionally, Brazilian sociologist Jessé Souza argues that black and poor women have found their social and economic position in Brazil during the transition from slavery to modern society throughout their labor role as domestic workers. He claims that domestic work has created many matrifocal families in Brazil, in which women represent the economic and social stability (SOUZA, 2017). The need for monitoring and implementing domestic workers' rights (INTERNATIONAL..., 2016) is recognized by workers unions that have mobilized a change in their -often oppressive- working conditions (BERNARDINO, 2014). The limited negotiating power with regards to work conditions and severe lack of access to alternate forms of work, has contributed to domestic work being perceived as servitude (BERNARDINO, 2014). One of the factors contributing to this perception of servitude is the domestic workers' work conditions. Although domestic work is socially useful, the remuneration for this work or the paternalistic employer-employee relationship reflects an under-valuing of this work. Instead, work environments may lead to domestic workers experiencing occupational injustice (GALVAAN, 2000, 2011). Townsend and Marval (2013) advocate that insights into people's unjust experiences may offer guidance as to how to promote occupational justice. Occupational injustice is broadly defined as the "exclusion as well as on the imposition of occupations in which individuals might not wish to engage or that might be detrimental to their well-being" (HAMMELL; BRENDA, 2017, p. 64.) Occupational injustice occurs when resources and opportunities for participation are inequitably distributed such that individuals are unable to experience wellbeing through occupational engagement.

Research with live-in domestic workers in a similar context of social inequality, that is, in South Africa, identified that the domestic workers experienced forms of occupational injustice (GALVAAN, 2011). The limitations imposed predominantly by domestic work together with their histories of intergenerational poverty (external factors) contributed to the domestic workers engaging in few meaningful activities and experiencing occupational deprivation. The definition of occupational deprivation refers to the outcomes of structural factors that negatively affect one's health and well-being (STADNYK; TOWNSEND; WILCOCK, 2010). The domestic workers also experienced characteristics of occupational imbalance, meaning that women experienced being un-occupied, under-occupied, and over-occupied (TOWNSEND; WILCOCK, 2004). Among live-in domestic workers it represents little time for rest; long work hours and a low participation in purposeful occupations. Their experience of occupational injustice, that had these features of occupational deprivation together with occupational imbalance was termed 
as occupational restriction. Occupational restriction reflected the domestic workers' submissive response to the discriminatory context which limited their occupational engagement. Domestic workers responses were individualised even though the causal factors were structural, such as socio-economic and race relations within the context (GALVAAN, 2011). Although dissatisfied, the domestic workers appeared to comply with the employers' expectations to be in service to and often subordinate as beings within the workplace. This was reflected as internalized oppression since the workers mostly prioritized the employers over themselves (GALVAAN et al., 2015) and tended to find ways to cope with their work situations by complying to the work demands that they faced. Galvaan's (2011) concept of occupational restriction draws attention to the relationships between forms of occupational injustice, demonstrating how internalized oppression may maintain such a situation. In this instance it limited them in being able to find options for alternate work (GALVAAN, 2000, 2011). This experience of occupational restriction contributed to domestic workers remaining submissive through their everyday occupational choices (GALVAAN, 2015). Although domestic workers exercised their agency, they conceded to many of the challenges within their contexts, merely negotiating a compromise to their rights within the oppressive work environment, and, with little power, they obtained small gains that did not allow them to fully experience wellbeing. For example, they would start work earlier on weekends and then have a small proportion of time off to socialize or rest during the weekend. In so doing they did their best by substituting occupations for others within an oppressive environment without developing the critical consciousness and recognition of the collective struggle faced by domestic workers. It is suggested that the latter is necessary to respond to the systemic and structural factors leading to their oppression. Their concession to the environment only allowed them to exercise limited agency so that they could participate in some health promoting occupations that did not challenge the status quo of their work environments, this was seen as occupational reconciliation (GALVAAN, 2000). In other words, the occupations that domestic workers participate in contributed to maintaining their social marginalization (GALVAAN, 2015).

In this article we aim to explore live-in domestic workers' lifeworld perspectives. Our main question is: What are Brazilian domestic workers' experiences in participating in their occupations in everyday life? We also aim to critically discuss the results in relation to historical, social and economic factors that influence women's occupations.

\section{Brasília: The Futuristic Utopian City}

The study took place in the Federal capital of Brazil, Brasilia. This city has a unique and modernist architecture that was constructed in a plateau at the heart of the Cerrado, a Brazilian ecosystem of grasslands (also known as the Brazilian Savanna). Brasilia was imagined and built as a contrast to the country's colonial legacy in that the innovation resided in a planned and modernist design that distinguished itself from the baroque and classical architecture in the country's coastal capitals. The intention was to create a city without the social and aesthetic disturbance of favelas (slums). While the design aimed to symbolize a new beginning and hope for the country's future, poor social and urban measures perpetuated the widespread of social inequality. A growing number of low-income neighborhoods (LIMA, 2013) developed in the surroundings of the planned city. This was fueled by the fact that the Candangos (workers migrating from several parts of the country, mainly from the northeast region who built the city during the 50's and 60's) remained in the city. The original idea was that two thirds of these workers would go back to their hometowns once the city was constructed. Instead, these workers established small settlements and then brought their families. The consequence was a rapid population growth within the city, with people settling on the periphery after they were 'eradicated' from the inner city. At the time, the city and these surroundings were planned for about half a million inhabitants at most, but currently it has a population of about 3 million (SPENCER, 2009; TAVARES, 2015).

The unplanned but expanding population on the city's periphery reflected major social inequalities in Brasilia. The historical neglect of appropriate policy development and infrastructure for these settlements are still issues, where the lack of education, health, and urban facilities is often critical. Several settlements are not legally recognized by the regional administration; consequently, basic services such as potable water, sewer, urban planning, parks, school, and health services are unavailable. In contrast, the planned city of Brasília, which was named as the Plano Piloto, has plenty of institutional and economic resources. Indeed, a consolidated middle-class profit from an organized and secure urban space. Residential buildings are arranged among public parks and green areas, where playgrounds are neatly kept. Health 
and education services are accessible through public and private service providers, reflecting the drastic inequality between the planned and non-planned parts of the city (SPENCER, 2009).

Nowadays, many inhabitants of peripheral cities commute to work in Plano Piloto during the day. Thus, many doorkeepers (porteiros), gardeners, and domestic workers live in different administrative cities other than the planned city of Brasília (CARVALHO, 2008). The existence of this labor workforce creates a mechanism for high-income families to compensate for the lack of basic public services (such as day care) by privatizing these services (BERNARDINO, 2014). The relation between these 'low skilled', low-income working categories and people in middle- and upper-income classes can be recognized in numerous symbols and structures. For example, most buildings in Brazil continue to have two separated entrances and elevators: one labeled as 'Social' and the other, as 'Service'. Even new buildings are designed with a 'domestic area' (called dependência de empregada) that usually includes a small bathroom and bedroom. These spaces are designed to accommodate a live-in domestic worker. While the reasons for this layout may appear operational, it reinforces social divisions. The translation of this physical and architectural structure reveals how strongly Brazilian society distinguishes the place one holds in society (BERNARDINO, 2014).

\section{Method}

A qualitative phenomenological perspective was used to understand the reality of domestic workers (HITZLER; EBERLE, 2004). We aim to explore how domestic workers in Brasilia act and think about their daily occupations. A lifeworld perspective was deemed appropriate as it allowed researchers to learn about domestic workers' life. A phenomenological perspective allowed us to understand their experience and develop this into a reflexive form. We have used phenomenological perspective to frame our research question and guide our methodology. Additionally, we used a critical stance discuss the findings. By critical stance we refer to interest in explore power relations that result in privileges and disadvantages (JORGENSEN; PHILLIPS, 2002) This is a research project part of an experimental research laboratory called 'Terapia Ocupacional Candanga' (based at University of Brasília) aimed to understand the characteristics and experiences of everyday life of different social groups in the Central-West Region of Brazil. The large project is led by the first author, and the second author develop this research within the lab activities. The third author were invited to discuss data and write the manuscript due to her long interested and experience in research with domestic workers.

\subsection{Sample selection}

Purposive sampling (ETIKAN et al., 2016) was used to select the participants. Only women working as live-in domestic worker with at least one year of work experience were invited. In order to access possible participants, the first author approached porteiros of residential buildings in a middle-class neighborhood, Asa Sul. This approach to recruitment was adopted since porteiros and domestic workers are often socially connected, so the first author reasoned that they would be able to assist with referring possible participants. Indeed, these key informants assisted the recruiting process of all participants. Between August and September 2015, the first author visited about 25 buildings, and each building had around 90 apartments.

Seven porteiros were willing to help by contacting through the building intercom a live-in domestic worker. This prompt contact resulted in a first conversation between the researcher and the domestic workers. At this moment, the second author provided information about the research aims and procedures, invited the woman to participate, and scheduled the interview. Five out of seven domestic workers contacted agreed to participate. Despite the researcher availability and flexible schedule, two domestic workers did not agree to participate arguing that they had the time to talk neither at that point nor at some point later. All the participants had the option to refuse to participate in the interviews without any coercion or pressure from the researcher. The participants were between the ages of 20 to 35 years old. Despite this young age range, most participants had more than a decade of experience as live-in domestic workers. Table 1 presents a profile of the participants. The names are not presented, and the women are identified by pseudonyms.

\subsection{Semi-structured interviews}

The second author collected data through semistructured interviews. One face-to-face interview was conducted with each participant. The interviews were conducted in diverse, agreed upon settings such as at a snack bar or in public parks. Each interview lasted about 40 minutes and when needed, participants were contacted by phone to clarify or 
Table 1. Characteristics of the participants.

\begin{tabular}{lllrc}
\hline $\begin{array}{c}\text { Pseudonyms, } \\
\text { age }\end{array}$ & $\begin{array}{c}\text { Birth State, } \\
\text { distance from } \\
\text { Brasilia }\end{array}$ & \multicolumn{1}{c}{ Level of education } & $\begin{array}{r}\text { Time in the } \\
\text { currently job }\end{array}$ & $\begin{array}{c}\text { Time working as a } \\
\text { domestic worker }\end{array}$ \\
\hline Marilene, 20 & PI, 1,872 Km & Studying at night: Secondary & 9 months & 3 years \\
Elizete, 26 & MG, $100 \mathrm{Km}$ & Studying high school: Online & 24 months & 14 years \\
Raimunda, 27 & PI, 1,466 Km & Primary education incomplete & 24 months & 11 years \\
Antonia, 24 & RN, 2,448 Km & Secondary education completed. & 30 months & 13 years \\
Lindaura, 35 & MA, 1,795 Km & Secondary education completed. & 36 months & 25 years \\
\hline
\end{tabular}

elaborate on some information missed during the interview. The interviewer was sensible and open to the interviewees' preferences regarding location and time for the interviews. All interviews were recorded and transcribed in Portuguese shortly afterwards by the second author, and all transcriptions were reviewed by the first author. Only selected quotations were translated into English.

\subsection{Data analysis}

An inductive thematic analysis was guided by the steps of Systematic Text Condensation (STC) (MALTERUD, 2012). STC was select to data analysis because it aims to explore people's life, not covering the full range of potential available phenomena based on a limited number of participants. Additionally, this approach has been used in research that explore women experiences (WEGNELIUS; PETERSSON, 2018). This data analysis was conducted as a collaborative negotiation between the three authors. The procedures of systematic text condensation (STC) includes four steps as follows: (i) total impression: In this step, the first and second author read the transcriptions individually to familiarize themselves with the data gathered. Then they discussed the impressions and insights that emerged from this initial reading; (ii) identifying and sorting meaning units: This step involves identifying and sorting meaning units to identify codes. Codes were generated and reflected the meaning units embedded within each interview. Once all the text was coded, the three authors engaged in further discussions in order to explore the accuracy of the codes and reach consensus on the label of each meaning unit. Several revisions of this process were conducted, as code labels were added/eliminated and changed; (iii) condensation: Based on the relationship between the codes and the interpretation that was extracted, the codes were organized into categories and a theme; and (iv) synthesizing: In writing up the findings, the concepts conveyed were described, synthesized and discussed in relation to available literature. This is reflected in the discussion section of this paper.

\subsection{Trustworthiness}

Some strategies were used to ensure trustworthiness, including (i) credibility, specifically researcher triangulation (CURTIN; FOSSEY, 2007; KORSTJENS; MOSER, 2018): in-depth, discussions and contextualization of the findings were provided by a multilingual and multicultural collaboration when documenting the study. The second author became involved during this phase of the study; (ii) reflexivity, (KORSTJENS; MOSER, 2018): the authors were committed to self-reflection and their own biases, preferences and preconceptions over the issue. We placed our research engagement on women's working rights and promotion of occupational justice.

\section{Ethics}

The Ethical Committee of the Humanities Faculty at the University of Brasília evaluated the project and approved the study (n. 1130232). All participants were informed about the study's objective and procedures, including their rights of anonymity and the option to leave/interrupt the interview at any moment. All participants signed a consent form, voluntarily agreeing to participate in the study. Participants were given a copy of this consent form.

\section{Findings}

Drawing from the data analysis, we identified one theme and two categories. The theme 'Grappling with being a domestic worker' described the domestic workers ongoing confrontations and tensions experienced in their daily lives. This theme included two categories, namely a sense of 'belonging to the labor role' and 'negotiating patterns of employer exceptionalism'. The following section describes the categories and then explains the theme. 


\subsection{Category 1: belonging to the labor role}

The notions of possible labor options were constructed very early in the life of the participants. The participants' living situation influenced their engagement in domestic work at a very young age. Lindaura, who started to work as a live-in domestic worker in her childhood, shared her experience about the way work was prioritized over schooling for her. It is worth mentioning that she did not receive a salary at that moment; instead, she worked in exchange for accommodation and food.

[...] when I was ten years old, I was already working hard. I went to school. I went to school when I was fourteen, fifteen to learn how to write my name [...] where I lived, where I used to live (former employers' houses), they (employers) told my mother that I would go to school, but they never enrolled me in one school (Lindaura).

Since the participants entry into domestic work at a young age was paired with low levels of formal education, this narrowed their further labor possibilities. Most of the participants in this study were from the northeast region of the country, which is a region known for its dramatic infrastructural and for its educational and welfare deficiencies that indicate difficulties to access public education during childhood. Raimunda expresses such experience and adds that besides better educational services in Brasilia, she has not been able to finish primary school after a decade living in the federal capital.

There was not enough time. When, when ... every time I've started (attending school) soon after I would give up, because the classes were in the evening [...] there (her hometown), there was no eighth grade, then I came here (Brasília) when I was sixteen and until now, I haven't finished primary school (Raimunda).

Migration motivated by the guarantee of getting a job as a live-in domestic worker was naturalized through their context, family, and themselves. Marilene and Lindaura moved from a poor region of Brazil to work as domestic workers in the federal capital; one was invited by her aunt and the other, by a friend. However, both were seemed as domestic workers, and moving to hold this position was naturalized by them. Keeping their role as a domestic worker resonated as a pathway within the social systems for all the participants

My aunt came here (Brasilia) to work. Then, I came to work here because my aunt was working with their (employers') relatives. She asked me if I wanted to come, and I said 'yes' (Marilene).

A lady that has been here (Brasilia) for ten years now brought her sister, who is a real friend of mine. After four months working here, she (her friend that was invited to work as a domestic worker by her sister) told me "Laurinda, you really like to work, right?", and here they pay very well for domestic workers (Lindaura).

They found few opportunities to negotiate labor conditions since their early work experiences. Some participants had previous experiences with precarious working conditions, and difficult economic conditions that sometimes led them to extreme situations. What this quote suggests is that Lindaura had a severely limited range of occupational choices available to her, both symbolically through the dispositions that she had developed and practically as a member of a working-class family. She saw herself as presented with very limited alternate labor options: one where work did not have an economic compensation but was centered in exchange for clothes and food, and another option was prostitution and even theft as a resort.

Lindaura: I even worked in a farmhouse in exchange for things.

\section{Researcher: What things did you receive?}

Lindaura: I received things like clothes, used ones; food $-1 \mathrm{Kg}$ of rice or beans things like this. There was a time when I worked for 30 Brazilian Reais a month (Approx. 12 USD). So, I did everything to work and maintain myself an honest person, you see? This way I didn't have to take someone else's things. I didn't have to... I don't know... to turn to prostitution. So, I preferred to receive things in exchange for my work, and I worked a lot and earned a little because it was the honest thing to do.

In these instances, they felt the long-term burden for being a domestic worker and expressed a desire to live in their own domestic environment. The participants also expressed that they had relatives in their birthplace, being most of them in the northeast region. They maintained contact by telephone and saw them during the holidays when they went back to their hometowns. Being a domestic worker guaranteed the participants some financial independence and allowed them to contribute financially to their family. They experienced a feeling of distance within social and cultural dynamics of Brasília. As workers in distant locations, the 
participants knew a few people in the areas where they lived and worked. Their acquaintances were mostly relatives and friends from their hometown who lived in different administrative regions of the Federal District, which are distant from their working places.

It is not what I planned for my life, staying longer working here [...] I want to get away, to go back near to my family (Marilene).

Interviewer: Do you have any relatives here (in Brasília)?

Antonia: No, I am the only one living here. I just talk to them over the phone. And I visit them on my vacations. In December, when I take my vacations, I go there (family's city) and celebrate Christmas' and New Year's Eve with them.

Notwithstanding, the participants share that Brasilia offers more and better job opportunities in comparison to their hometown. The participants' views of good working conditions were based on their previous work experiences as a standard, rather than the improvement of basic conditions of labor law.

There (referring to a previous work) I took care of a child and it was very hard because I only earned 350 Reais (about 140 USD) monthly. And, for me it was much harder than working here; I barely had free time. I think that it is easier to work here (Marilene).

The participants emphasized many burdens related to identifying themselves as belonging to the group of 'live-in domestic worker'. The architecture of the city is one of the points that was highlighted by some of the participants as a relevant element of the construction of social relations.

(In my hometown) I had more liberty. I feel that there you can go to other places, you can visit relatives, you have somewhere to go. Not here. [...] I see the sunrise and sunset from inside the apartment; sometimes, I take the dogs for a walk. It's like this. It's not that I am a prisoner, I didn't end up a prisoner, because I have the liberty of going everywhere, but I think it is a little hard, it is strange (Marilene).

The experience of marginalization expressed as "hard" and "strange" was further expressed in the way that most of the participants referred to the difficulties of maintaining a stable relationship due to their everyday labor structure. The participants suggested that there is an incompatibility between a life of a live-in domestic worker and the fulfillment of their conjugal and maternal intentions. Indeed, the possibilities of participating in different job positions were limited by the participants' social situation, and these possibilities re-enforced the limited way that they saw themselves as workers. However, this feeling of fitting in and accepting their social position was confronted when they pursued personal relationships, namely when they found a boyfriend and/or got married.

\section{I like it, but at the same time I don't. In the beginning, I liked it, but now, now I would prefer to go back home. We also get tired of sleeping at the workplace. Even if people get tired of taking crowded bus to arrive late at home, I like going back home. When I go, I enjoy it (Raimunda).}

\section{I always lived in my employer's house since I was 10-year old. So, I even tried to have a husband and everything, but it didn't work. Then, I went back to work (and live) at the employers' house [...] (Lindaura).}

The tension that the domestic worker felt led her to embrace and accept the additional challenges of commuting home even when she was tired. They also claimed that they had more fun and social activities in their hometowns. Leaving their hometowns led to a reduction of social networks as their current locations limited the possibilities of participating in occupations that were socially and collectively constructed. They experienced a feeling of distance within social and cultural dynamics of Brasília. As workers from distant locations, the participants knew few people in the areas where they lived and worked. The identity of being a domestic worker and embodying what it meant to belong to this labor role had an impact on the kinds of participation and occupational choices available to the domestic workers.

Here barely know people, I know the doorkeeper, the janitor, these people, but the neighbours, I know nobody (Antonia).

She (employer) invited me to go out with her during the weekends, but I felt awkward. I didn't feel well; I would prefer to stay at home (Antonia).

Finally, they expressed desires for different work forms, as indicated by Marilene and Lindaura. While Marilene expressed her desire for entrepreneurship, Lindaura expressed her interest in formal knowledge.

Researcher: You said that you are saving money to open a small business. Thus, does it mean that you no longer want to work as a domestic worker? 
Marilene: No, it's not that that I want for me. I don't want to stay working here for much longer.

I think about enrolling in a course, to learn. How do you call it? Nursing, or something like that [...] I still want to do it for the knowledge, you see? [...] I know that I must do something (Lindaura).

\subsection{Category 2: exceptionalism: an employers' negotiation tactic}

The participants described that the activities included in their labor contract mostly shifted over time and were according to the employers' interest. They described this shift occurring in their everyday experience rather than in the written contract. The participants reported that their schedules were always established and organized according to their employers' routines and needs. The terms of the schedules were usually agreed on with the employer and depended on the time that various members of the household began their work/school/leisure activities. Domestic workers help employees smoothly navigate in their daily life. The women assumed the responsibility for going beyond the previously established work schedule, mostly because they were available and were already at the workplace, as the examples shared by Raimunda and Marilene.

Usually, I prepare the girl' breakfast (employers' daughters). Then I do laundry, play with the kids and cook lunch. When the girls are at school, I take care of the house; I clean the living room, the kitchen, the bathrooms [...] (Raimunda).

Marilene: I should start to work at 8 AM, you see? But as I wake up early, I get things done ahead. Then, I do breakfast, then he has it because he studies in the morning. Then, she goes to work and drives him to school.

Researcher: What time does she goes to work?

Marilene: She leaves home 7:30 AM

Researcher: So, if you started to work at 8:00 AM, there would be no time to prepare the breakfast?

\section{Marilene: Yes, I would not have to do the breakfast} if I lived somewhere else.

The live-in domestic workers had to maintain order in the house while simultaneously and constantly taking care of children, elderly people or a member of the family with disability. Their working day ended when the people they took care of went to sleep or the employers took over the responsibility of those 'vulnerable' people in the household. This additional responsibility to take care of someone was presented in most of the participants' experiences, and it was negotiated throughout time. The domestic workers in this study had little room to negotiate their working conditions; they described how their employers determined their working conditions. The excessive power that employers held over these conditions appeared to be evident in that sometimes activities were explained, but usually their labor agreements were a combination of different responsibilities that developed as the employer required. The evolving roles and duties were highlighted by a participant whose duties were determined by the employer's work schedule:

In the beginning, I started to work only taking care of the child, because he has a mild deficiency, you see? But then they came and asked me to take care (clean) of the house also. I've been here 9 months now (Marilene).

[...] I am a baby-sitter and I take care of the house. Children need more attention, and their parents arrive late; and there are times when they don't arrive on time to put the children to bed. So, you see? I stay (working late) because she (the employer) doesn't keep a strict schedule to arrive (Elizete).

Participants were presented with new and different tasks over time and expressed difficulty in negotiating and establishing boundaries. For Elizette, her contract did not help her to navigate or manage the additional aspects added to her job. Likewise, Antonia had difficulties describing the limits of her responsibilities.

I do not know what is defined in my employment contract, but I think it is like domestic worker. Usually I do both (baby-sitting and take care of the house); I am ... a domestic worker (Elizete).

Researcher: What do you do in their house?

Antonia: Everything.

Researcher: What do you mean by 'everything'?

Antonia: I mean cleaning, laundry, and when she goes out, I take care of her newborn baby. Now she'll start working again, so I'll have to look after the children and do all the cleaning, the laundry, and the cooking.

During the weekend, participants shared that their schedules for leaving and returning from free time were predefined and fixed. However, they often 
used these periods to complete unfinished tasks from the regular weekdays. For example, Marilene irons clothes on Saturdays and Sundays when she is not able to finish it during the workweek.

I just do what is needed, like cooking because she came home to have lunch every day, then, it is necessary, you see? But iron clothes there is no problem to be done on Saturday or Sunday, you see? (Marilene).

Informal agreements and what are labeled as appropriate and inappropriate varied according to the dynamic of the household. The full legal recognition of their rights by the employers was missing. Instead, there was a space for compensation that usually and temporally satisfied the participants.

During the weekends, he (my partner) doesn't work and we go to his family house. I go with him on Saturdays and get back on Mondays. Usually, it's like that, but there are weekends that she (employer) needs to attend a dinner or something else, [...] then I have to stay with the kids. They pay me some extra hours (Antonia).

The informal forms of compensation are proposed by the employer and accepted by the employees. Negotiations and agreements were mainly presented as informal adaptations of tasks and activities. They represent a consensual agreement of chores in which both parties would benefit from, and they might be sporadic or part of their routine. Although participants mostly had good relations with employers, they were aware that there were limitations in how they related to each other.

We stay talking, or [...] doing random things on the Internet; she (employer) shows me a lot of stuff. We talk as friends, you know? But I won't tell her everything and she won't tell me everything, you see? There are limits; the thing is to chit-chat (Lindaura).

Even if women were active individuals with agency, we cannot analyze these negotiations ignoring the dynamics of power in their context. The employers' negotiation tactics of framing request as exceptions shape live-in domestic work. They undertook an informal negotiation on their daily schedules, taking time off during holidays and even weekends. The negotiation of agreements yielded practical dimensions of compensation in terms of social security and free time. Lindaura recalls her concerns about social security and her disappointment.
I used to work for a town councilor there (her birth town). My salary was about $R \$ 500,00$. And I did everything. I asked several times for them to sign a formal contract (carterira de trabalho), then I would be covered by social security (INSS). You know, you must pay tributes to retire, but he said that he couldn't do that because he had no conditions. [...] even if the salary was little, I needed to work. Thus, I had to bear, bear, bear. So, when a new opportunity would come, I would accept at once (Lindaura).

The participants also described exchanges for favors as influential in their occupational choices. A consideration by employers was demonstrated when they invited their employees to non-working activities; for instance, an invitation to a theatre course or trips. Additionally, employers offered to solve problems that employees might have, such as having difficulty to make a physician appointment. In these instances, the employers could draw on their social capital and positions to leverage assistance for the domestic workers. Usually these agreements were convenient for the employers, but they do not necessarily represent an advantage for the participants. For example, Marilene recounted that her boss wanted her to take a theatre course. The employer registered the employee and herself. She paid her to accompany her because she did not want to go alone. Once the employer got to know other people taking the course, she stopped paying the course for her as she did not need her company any more even though she had gotten interested in the course.

These exchanges for favors were apparently viewed as win-win situations, in which both parties obtained something they needed or desired. However, these mutual considerations are contradictory and unbalanced.

\subsection{Theme: grappling with being a domestic worker}

The participants contended with the demands of being domestic workers as they felt torn between hometown and working location, between past and current situations, between 'being born' into a domestic workplace and the possibility to choose otherwise. Having to be a person who lives in two very different social and economic worlds left the domestic workers experiencing a sense of grappling in their everyday doing.

The participants' experiences of feeling isolated in the city but committed to their roles and identities as domestic workers left them with a fractured sense of 
belonging. Their previous social roles with relatives, friends, and acquaintances were surpassed by the imperative to fulfill an economic role. Negotiations on what to do and what they could do were an everyday characteristic of live-in domestic workers life as they asserted their agency within the limitations of their contexts. These negotiations and the conditions of their work influenced the domestic workers' personal life in such way that even their occupations outside the work were usually subject of employer's choices and situations. In this sense, interruptions and adaptations from the employers became part of their everyday life. It is worth noticing that these 'exceptional' adaptations are not isolated cases but constitute an effective employers' negotiation tactic where the employers' needs were seen as a constant exception that had to be negotiated due to the practical elements of everyday life and emotions of both employer and employee. This strain was experienced by domestic workers in fulfilling their roles and identities of being a domestic worker and trying to negotiate space for themselves as people within a context where the employers' power was demonstrated in the constant prioritization of the employers' needs over theirs.

\section{Discussion: Identifying Nuanced Forms of Occupational Injustice}

In Brazil, social programs only reached most of the population during the first decades of the $21^{\text {st }}$ century (SOARES et al., 2010), and have not yet prevented flows of internal migration. Domestic work fulfills the necessity for housing and food, which are neglected by a weak welfare and educational system. The State's negligence to provide access, such as access to opportunities for formal education, perpetuates cycles of poverty impacting the limitations of some (SILVA; HASENBALG, 2000). Women employed as domestic workers embody how the restricted possibilities in early life are difficult to reverse when social inequality persists. The findings showed the domestic workers current situation and their experiences since early childhood, which left them with limited social, capital, and educational qualifications that could allow them to have access to work beyond domestic labor. This lack of access and support should be considered without apportioning blame to the family members or the women. In Brazil, quite often people in vulnerable conditions have been blamed by their precarious living conditions (SOUZA, 2017). Instead, we highlight the scarcity of opportunities faced by many Brazilian women who are domestic workers. This reflects the continuation of historically solidified unequal and racist patterns of narrow women's opportunities in Brazilian society (BERNARDINO, 2014). In this sense, domestic workers have historically limited opportunities to engage and pursue diverse occupational choices due to consolidated social structures. While this reflects the situated nature of occupational choice (GALVAAN, 2015), we further argue that early experiences of occupational deprivation, in which options and opportunities were scarce, shape a sense of belonging to the labor role as domestic workers in adulthood. For example, while the women had limited access to formal educational opportunities while growing up, they had experience of doing different menial work to earn an income. Given their personal histories, domestic work resonated with them and emerged as a familiar, viable and accessible form of work. This is supported by the view that individuals may reproduce the unexamined, oppressive assumptions about how and what they are expected to do and be in the communities that they are a part of (GALVAAN, 2011). Doxa, in Bourdieu's terms, refers to the consensual opinion, shown here in their familiarity and resonance with domestic work, which frames the social dynamic (BORDIEU, 1984). This doxa exists as the unquestioned assumptions are often shared by the majority of members of a marginalized community (GALVAAN, 2015). The unexamined assumptions about the low value and expected subservience of domestic workers (that is, the doxa) led to domestic workers' recurring occupational choices perpetuating subservient ways of engaging in occupations. In so doing, maintaining the status quo of occupational deprivation.

The findings of this study also showed that factors associated with the domestic workers' social position, that is, their social class, gender and race identities affected their agency in negotiating different work conditions. These categories of social identity are components of intersectional identity (YUVAL-DAVIS, 2006) and are known to shape how domestic workers exercise their agency (BERNARDINO, 2014).

While the implementation of the Constitutional Amendment 72 on domestic work in Brazil has had a moderate effect on the work conditions of domestic workers (INTERNATIONAL..., 2016), the experiences of domestic workers in this study support that more research and advocacy is needed to dignify domestic work. 
Brasília’s strong architectural barriers dividing social groups and their activities has segregated certain populations and solidified divisions in the city, reflecting on how hard it was for domestic workers in this study to feel integrated. Indeed, domestic workers engaged in certain negotiations with their employers, but more often they benefit the latter. The exchange for informal favors and the adaptation to the un-planned demands of the employer mark the routine of live-in domestic workers. Employers seeking occupational balance constantly adapted their schedules. Occupational balance is 'defined as the individual's perception of having the right amount of occupations and the right variation between occupations' (WAGMAN; HÅKANSSON; BJÖRKLUND, 2012, p. 322). In this sense, our findings indicate that for employers gaining occupational balance to engage in social and labor activities happens at the expense of the employees, who lose freedom and possibilities. This paradoxical relationship was often expressed in ambivalent feelings. This discussion would surely profit from the analysis on the individual limits to pursue occupational balance in such context, and crossing analysis between occupational balance and occupational injustice are required. Similarly, a research with domestic worker employers' in South Africa (GALVAAN et al., 2015) showed that employers continued to prioritize their needs without consideration for the consequences that this had on domestic workers. From the domestic workers' perspective, the current study showed that the domestic workers attempted to negotiate within the boundaries of their oppressive (work) contexts. During these negotiations, domestic workers attempted to create spaces for what they needed in their occupational engagement, such as opportunities for social activities. This study shows that such substitution is not as optimal, and it does not engage on the social conditions affecting domestic workers. We argue that the concept of "occupational reconciliation" (GALVAAN, 2000) occurs as a response to situations of occupational injustice in which people try to find ways to make their situations bearable, without significant changes to these situations. This seems to be the case of the domestic workers in this study, as they move forward their life as individuals without being able to effect any structural changes. This may apply to many domestic workers who are not part of a collective, such as a domestic worker union or a co-operative, which could advocate for structural, systemic change.

Our discussion contributes to critically analyze how external, historical, social and political factors in oppressive environments influence a group of live-in domestic workers. Brazil, as other countries in the world, has a history of social and racial divisions that has been so strongly consolidated that it limits the life of some and, particularly, their participation in occupations. An appreciation of the way that domestic workers participate in occupations in the context of oppression has implications for occupational therapists to work with domestic workers. In this article, we moved our attention away from those who have been recognized as a usual occupational-therapy clientele. In this sense, learning about the everyday life of domestic workers from an occupational perspective means a contribution to overcome professional dominance, standardized notions of care and market-driven interventions. We believe that the Capability Approach might be a useful tool to address not solely the women abilities but also their experience of freedom/opportunities that results from the combination of personal abilities and resources, the social, political and economic environments, and context history (HAMMELL; BRENDA, 2017; HAMMELL, 2017).

This research has some limitations including: (i) a limited number of interviews that might limit the power of the information collected; (ii) Brasilia's unique dynamic, which does not make our findings a countrywide representation of other live-in domestic workers; (iii) the date of the data collected, which happened in 2015 when the law that guarantees work rights to domestic workers was enacted. In this sense, new research is required to explore how employer's negotiation tactics might have changed. Likewise, future research should explore the situatedness of domestic workers' occupations to understand their position and the way they build possibilities in life.

\section{Acknowledgements}

Vagner and Izabella would like to thank Professor Olga Ramalho for her comments in the first draft of this article. Vagner and Izabella acknowledge the undergraduate occupational therapy students Amanda Santos, Graciene Tavares, Nathalia Viana, Barbara Costa, Raphael Thabo, for their participation in the 'Terapia Ocupacional Candanga' meetings, in which the data was analysed.

\section{Referências}

ALMEIDA-FILHO, F. N. et al. Social inequality and depressive disorders in Bahia, Brazil: interactions of gender, ethnicity, and social class. Social Science \& Medicine, New York, v. 59, n. 7, p. 1339-1353, 2004. 
ARAUJO, S. G.; GONZÁLEZ-FERNÁNDEZ, T. International migration, public policies and domestic work: latin American migrant women in the Spanish domestic work sector. Women's Studies International Forum, Birmingham, v. 46, p. 13-23, 2014.

BERNARDINO, C. J. Intersectionality and female domestic workers' unions in Brazil. Women's Studies International Forum, Birmingham, v. 46, p. 72-80, 2014.

BORDIEU, P. Questions de sociologie. Paris: Les Éditions de Minuit, 1984.

BRASIL. Lei Complementar no 150, de 1 de junho de 2015. Dispóe sobre o contrato de trabalho doméstico. Diário Oficial [da] República Federativa do Brasil, Poder Executivo, Brasília, DF, 1 jun. 2015. Disponível em: <http://www.planalto.gov.br/ccivil_03/leis/LCP/Lcp150. htm>. Acesso em: 13 fev. 2017.

CARVALHO, D. L. Mobilidade urbana e cidadania no Distrito Federal: um estudo do programa Brasília integrada. 2008. $124 \mathrm{f}$. Tese (Mestrado em Sociologia) - Universidade de Brasília, Brasília, 2008.

CHOR, D. Desigualdades em saúde no Brasil: é preciso ter raça. Cadernos de Saúde Pública, Rio de Janeiro, v. 29, n. 7, p. 1272-1275, 2013.

CURTIN, M.; FOSSEY, E. Appraising the trustworthiness of qualitative studies: guidelines for occupational therapists. Australian Occupational Therapy Journal, Australia, v. 54, n. 2, p. 88-94, 2007.

DIEESE. As características do trabalho doméstico remunerado nos mercados de trabalho metropolitanos. São Paulo: Dieese, 2010. Disponível em: <https://www.dieese.org.br/estud osetorial/2011/2011 trabDompedmet.pdf $>$. Acesso em: 24 jun. 2015.

ETIKAN, I.; MUSA, S. A.; ALKASSIM, R. S. Comparison of convenience sampling and purposive sampling. American Journal of Theoretical and Applied Statistics, New York, v. 5, n. 1, p. 1-4, 2016.

FRANK, G.; ZEMKE, R. Occupational Therapy foundations for political engagement and social transformation. In: POLLARD, N.; SAKELLARIOU, D.; KRONENBERG, F. (Ed.). A political practice of Occupational Therapy. New York: Elsevier Health Sciences, 2008. p. 111-136.

GALVAAN, R. The live-in domestic workers' experience of Occupational engagement. 2000. $92 \mathrm{f}$. Dissertation (Master in Occupational Therapy) - University of Cape Town, Cape Town, 2000.

GALVAAN, R. Domestic workers' narratives: transforming occupational therapy practice. In: KRONENBERG, F. et al. Occupational therapies without borders: towards an ecology of occupation-based practices. Edinburgh: Churchill Livingston/Elsevier, 2011. p. 429-439.

GALVAAN, R. et al. Employers' experiences of having a live-in domestic worker: insights into the relationship between privilege and occupational justice. South African
Journal of Occupational Therapy, South Africa, v. 45, n. 1, p. 41-46, 2015.

GALVAAN, R. The contextually situated nature of occupational choice: marginalised young adolescents' experiences in South Africa. Journal of Occupational Science, London, v. 22, n. 1, p. 39-53, 2015.

GUAJARDO, A. Una Terapia Ocupacional crítica como posibilidad. In: SANTOS, V.; GALLASSI, A. (Ed.). Questōes contemporâneas da Terapia Ocupacional na América do Sul. Curitiba: CRV, 2014. p. 159-165.

GUTIERREZ-RODRIGUEZ, E. Domestic workaffective labor: on feminization anthe coloniality of labor. Women's Studies International Forum, Birmingham, v. 46, p. 45-53, 2014.

HAMMELL, K. W. Quality of life, participation and occupational rights: a capabilities perspective. Australian Occupational Therapy Journal, Australia, v. 62, n. 2, p. 78-85, 2017.

HAMMELL, K. W.; BRENDA, B. Occupational injustice: a critique. Canadian Journal of Occupational Therapy, Thousand Oaks, v. 84, n. 1, p. 58-68, 2017.

HITZLER, R.; EBERLE, T. S. Phenomenological Lifeworld Analysis. In: FLICK, E.; STEINKE, A. Companion to qualitative research. London: Sage, 2004. p.67-71.

INTERNATIONAL LABOUR OFFICE - ILO. Domestic workers across the world: global and regional statistics and the extent of legal protection. Geneva: ILF, 2013.

INTERNATIONAL LABOUR OFFICE - ILO. Initial effects of Constitutional Amendment 72 on domestic work in Brazil. Geneva: ILO, 2016.

JORGENSEN, M.; PHILLIPS, L. Discourse analysis as theory and method. London: Sage Press, 2002.

KOFES, S. Mulher, mulheres: identidade, diferença e desigualdade na relação entre patroas e empregadas domésticas. São Paulo: Editora Unicamp, 2001.

KORSTJENS, I.; MOSER, A. Series: practical guidance to qualitative research - Part 4: trustworthiness and publishing. London: European Journal of General Practice, 2018.

LIMA, L. L. The persistent inequality in the great brazilian cities: the case of Brasília. Brasília, 2013.

MALTERUD, K. Systematic text condensation: a strategy for qualitative analysis. Scandinavian Journal of Public Health, Sweden, v. 40, n. 8, p. 795-805, 2012.

MCCALLUM, C. Racialized bodies, naturalized classes: moving through the city of Salvador da Bahia. American Ethnologist, Amsterdam, v. 32, n. 1, p. 100-117, 2005.

SILVA, N. V.; HASENBALG, C. Tendências da desigualdade educacional no Brasil. Dados, Rio de Janeiro, v. 43, n. 3, p. 423-445, 2000.

SOARES, F. V.; RIBAS, R. P.; OSÓRIO, R. G. Evaluating the impacto $\mathrm{fBrazil}$ 's bolsa família: cash transfer programs 
in comparative perspective. Latin American Research Review, Baltimore, v. 45, n. 2, p. 173-190, 2010.

SOUZA, J. A elite do atraso: da escravidão à lava jato. Rio de Janeiro: Casa Editora Casa de Palavra, 2017.

SPENCER, A. The informal architecture of Brasilia: an analysis of the contemporary urban role of its satellite settlements. In: HERNÁNDEZ, F.; KELLETT, P.; ALLEN, L. K. (Ed.). Rethinking the informal city: critical perspectives from Latin America. London: Berghahn Books, 2009. p. 54-70.

STADNYK, R.; TOWNSEND, E.; WILCOCK, A. Occupational justice. In: CHRISTIANSEN, C. H.; TOWNSEND, E. A. (Ed.). Introduction to occupation: the art and science of living. New Jersey: Pearson Education, 2010. p. 329-358.

TAVARES, B. Novos territórios da saúde do século XXI: o caso da RIDE-DF. In: MAZITELLE, F. et al. (Ed.). Desenvolvendo e articulando o conhecimento para o cuidado das pessoas em sofrimento pelo uso de drogas em contextos de vulnerabilidade. Curitiba: CRV, 2015. p. 23-34.
TOWNSEND, E.; MARVAL, R. Can professionals actually enable occupational justice? Cadernos de Terapia Ocupacional da UFSCar, Sáo Carlos, v. 21, n. 2, p. 215-228, 2013.

TOWNSEND, E.; WILCOCK, A. Occupational justice and client-centred practice: a dialogue in progress. Canadian Journal of Occupational Therapy, Thousand Oaks, v. 71, n. 2, p. 75-87, 2004.

WAGMAN, P.; HAKANSSON, C.; BJORKLUND, A. Occupational balance as used in occupational therapy: a concept analysis. Scandinavian Journal of Occupational Therapy, Sweden, v. 19, n. 4, p. 322-327, 2012.

WEGNELIUS, C. J.; PETERSSON, E. L. Cultural background and societal influence on coping strategies for physical activity among immigrant women. Journal of Transcultural Nursing, Alabama, v. 29, n. 1, p. 5463, 2018

YUVAL-DAVIS, N. Intersectionality and feminist politics. European Journal of Women's Studies, London, v. 13, n. 3, p. 193-209, 2006.

\section{Author Contributions}

Izabella Oliveira Rodrigues: Study design; Data collection; Data analysis and interpretation; Drafting of manuscript. Roshan Galvaan: Drafting of manuscript; Critical revision. Vagner Dos Santos: Study design; Data analysis and interpretation; Drafting of manuscript; Critical revision. All authors approved the final version of the paper. 